\title{
LOW ENERGY AVAILABILITY IN A GROUP OF POLISH FEMALE SOCCER PLAYERS
}

\author{
Hubert Dobrowolskil, Dariusz Włodarek ${ }^{l}$ \\ ${ }^{1}$ Department of Dietetics, Institute of Human Nutrition Sciences, \\ Warsaw University of Life Sciences (SGGW), Warsaw, Poland
}

\begin{abstract}
Background: The most important element of a well-balanced diet is a proper energetic value. Energy deficiencies are often observed in athletes, especially women. Energy deficiencies can lead to low energy availability which can cause serious health problems and affect exercise capacities. There is, therefore, a risk of health complications and reduced physical performance among female soccer players.

Objective: The aim of this study was to check the frequency of low energy availability appearance in a group of women training soccer, which could results in negative health effects due to Relative Energy Deficiency in Sport (RED-S).

Material and methods: Thirty-one professional female soccer players practicing on different league levels (Extra-league, I league, II league) participated in the study. The participants had their height and body mass measured. To assess the Energy Intake the method of 3-day dietary food recording was used. Total Energy Expenditure (TEE) and Exercise Energy Expenditure (EEE) was measured by means of an Armband SenseWear Pro3 device. The content of fat free mass was assessed with Akern BIA 101 Anniversary Sport Edition device.

Results: The body mass median of participants was $58 \mathrm{~kg}$. The average height was $166 \pm 5 \mathrm{~cm}$, and the average BMI was $21.4 \pm 2 \mathrm{~kg} / \mathrm{m}^{2}$. TEE was $2703 \pm 392 \mathrm{kcal} /$ day, while EEE was $515 \mathrm{kcal}(203-597 \mathrm{kcal})$. Energy intake was $1548 \pm 452 \mathrm{kcal} /$ day. Energy availability was $25 \pm 11 \mathrm{kcal} / \mathrm{kg}$ fat free mass/day. Twenty of the study participants had low energy availability. The percentage of EEE in TEE was $17.93 \pm 3.14 \%$.

Conclusions: Low energy availability was demonstrated in the vast majority of studied group, which may lead to negative health consequences or reduction of exercise capacity.
\end{abstract}

Keywords: women; female athlete; low energy availability; exercise energy expenditure; female athlete triad

\section{STRESZCZENIE}

Wprowadzenie: Najważniejszym elementem dobrze zbilansowanej diety jest jej odpowiednia wartość energetyczna. Niedobory energetyczne są często obserwowane wśród sportowców, zwłaszcza kobiet. Niedobory energii mogą prowadzić do wystąpienia niskiej dostępności energii, co może powodować poważne problemy zdrowotne i wpływać na zdolności wysiłkowe. Istnieje zatem ryzyko powikłań zdrowotnych i obniżonej sprawności fizycznej wśród kobiet-sportowców, w tym żeńskich zawodniczek piłki nożnej.

Cel badań: Celem badań była ocena jaki odsetek kobiet trenujących piłkę nożną jest narażonych na negatywne skutki zdrowotne wynikające z niskiej dostępności energii oraz ryzyka wystąpienia syndromu względnego niedoboru energii w sporcie (RED-S). Material i metody: W badaniu wzięło udział 31 zawodniczek grających na trzech różnych poziomach ligowych (Ekstraliga, I liga, II liga). Zmierzono wysokość i masę ciała uczestniczek. Aby ocenić spożycie energii z dietą zastosowano metodę 3-dniowego bieżącego notowania. Całkowity wydatek energetyczny (TEE) i wydatek energetyczny w trakcie treningu (EEE) mierzono za pomocą opasek naramiennych SenseWear Pro3. Zawartość masy beztłuszczowej oceniono za pomocą urządzenia Akern BIA 101 Anniversary Sport Edition.

Wyniki: Mediana masy ciała uczestniczek wyniosła $58 \mathrm{~kg}$. Średnia wysokość ciała wynosiła $166 \pm 5 \mathrm{~cm}$, a średnie BMI $21,4 \pm 2 \mathrm{~kg} / \mathrm{m}^{2}$. TEE wynosił $2703 \pm 392 \mathrm{kcal} /$ dzień, podczas gdy EEE wynosił $515 \mathrm{kcal}$ (203-597 kcal). Spożycie energii wyniosło $1548 \pm 452 \mathrm{kcal} /$ dobę. Dostępność energii wynosiła $25 \pm 11 \mathrm{kcal} / \mathrm{kg}$ masy beztłuszczowej / dzień. Dwadzieścia uczestniczek badania miało niską dostępność energii. Procentowy udział EEE w TEE wynosił 17,93 $\pm 3,14 \%$.

Wnioski: Wykazano niską dostępność energii u zdecydowanej większości kobiet z badanej grupy, co może prowadzić do negatywnych konsekwencji zdrowotnych i/lub zmniejszenia zdolności wysiłkowych.

Słowa kluczowe: kobiety; sportsmenki; niska dostępność energii; wydatek energetyczny $w$ trakcie treningu; triada atletek

Corresponding author: Hubert Dobrowolski, Department of Dietetics, Institute of Human Nutrition Sciences, Warsaw University of Life Sciences (SGGW), 159c Nowoursynowska Str., 02-776 Warsaw, Poland, tel. +48 693208 788, e-mail: hubert_dobrowolski@sggw.pl 


\section{INTRODUCTION}

Diet is one of the important factors benefiting manual efforts. A well-balanced diet, which is calculated to satisfy the increased energy demand of athletes and provide the right amount of nutrients, helps to maximize physical efficiency during the sporting activities [11]. The most important element of a well-balanced diet is a proper energetic value. Appropriate energy intake is the cornerstone of the athlete's diet because it supports optimal body function, determines the capacity for the intake of macronutrient and micronutrients, and assists in manipulating body composition [1]. Energy deficiencies often observed in athletes, especially women, in turn, reduce physical performance, growth and adversely affect health [22].

Energy availability is a term which refers to the amount of energy available for metabolic processes after using some of the supplies needed for physical exercise and calculated per $\mathrm{kg}$ of fat free mass [32]. When energy availability is too low, body reduces the amount of energy used to maintain cell function, thermoregulation, growth, and reproduction. This compensation restores energy balance and increases survivability but, on the other hand, affect health negatively [29]. The proper energy balance for optimal health is $45 \mathrm{kcal} / \mathrm{kg}$ fat free mass/day [8], while negative health effects are observed when reducing the energy available to less than $30 \mathrm{kcal} / \mathrm{kg}$ fat free mass/ day [1].

Initially, among women practicing sport, attention was primarily paid to the female athlete triad, i.e. three components coexisting and dependent on each other low energy availability, menstrual disorders and low bone mineral density $[3,29,30,38]$. Although, in 2014 the International Olympic Committee expanded the known spectrum of disorders due to low energy availability (while stating that this problem does not only affect women) and name it Relative Energy Deficiency in Sport (RED-S) [27]. The consequences of low energy availability include serious health problems (impairment of immunological functions, menstrual functions disorder, osteoporosis, disorder of endocrine, metabolic, hematological, psychological, gastrointestinal, cardiovascular systems and growth disorder) and affect exercise capacities (increased injury risk, decreased training response, impaired judgment, decreased motor coordination and concentration, irritability, depression, decreased glycogen supplies, decreased muscle strength and stamina) [26, 27].

Only a few studies have investigated the amount of energy supplied with food ration in a group of female soccer players. Martin et al. (2006) in their research showed the energy consumption of $1904 \pm 366 \mathrm{kcal} /$ day $(30.9 \pm 5.5 \mathrm{kcal} / \mathrm{kg}$ body mass/day) [25]. Slightly higher values were obtained by Mullinix et al. (2003)
- $2015 \pm 19 \mathrm{kcal} /$ day (34 kcal/kg body mass/day) [28]. Clark et al. (2003) in their research based on female soccer players, which was conducted before and after the season, achieved comparable results $2290 \pm 310 \mathrm{kcal} /$ day $(37 \pm 5 \mathrm{kcal} / \mathrm{kg}$ body mass/day) in questionnaire obtained before the start of soccer season and $1865 \pm 530 \mathrm{kcal} / \mathrm{day}(30 \pm 18 \mathrm{kcal} / \mathrm{kg}$ body mass/day) after soccer season ended [9]. Gravina et al. (2012) received the energy value of food ration at the level of $2271 \pm 571 \mathrm{kcal} /$ day [14], and Gibson et al. (2011) $2079 \pm 460 \mathrm{kcal} /$ day $(35 \pm 10 \mathrm{kcal} / \mathrm{kg}$ body mass/day) [13]. In addition, if energy expenditure was measured in these studies, then in no case did the diet covered energy needs in the study group [13, 25, 28].

These studies showed energy consumption slightly higher than $30 \mathrm{kcal} / \mathrm{kg}$ body mass/day. This suggests that at least some of the tested female players did not exceed the limit of $30 \mathrm{kcal} / \mathrm{kg}$ fat free mass/day of energy available. In addition, research indicates energy deficits in the study groups. Therefore, there is a risk of health complications and reduced physical performance among female soccer players. The aim of this study was to check the frequency of low energy availability appearance in a group of women training soccer, which could results in negative health effects due to Relative Energy Deficiency in Sport (RED-S).

\section{MATERIALS AND METHODS}

This research involved 31 professional female soccer players playing professionally in different league-level clubs (Extra-league, I League, and II League; $n=13, n=11$, and $n=7$, respectively; according to the Polish soccer league system: Ekstraliga, I Liga, and II Liga, respectively). Mean age of the players was $21.5 \pm 4.9$ years old $(23.3 \pm 5.4$ years old; $20.1 \pm 4.6$ years old; $20.4 \pm 3.5$ years old for extra-league, I league and II league team, respectively). The research and all procedures were approved by the local Ethics and Scientific Research on Humans Commission (approval number: 24/2017, 19 June 2017). All participants or (if underage) their legal guardians consented to take part in the study, to have all the measurements taken and to undergo various tests during the research.

Inclusion criteria were: to be under 35 years old, to be registered in the local Soccer Association, and to take an active part in training sessions. The participants with long-term injuries (not permitted to train within the last 6 months), diagnosed with any long-term disease, those who underwent metal implants operation, and those who had failed to submit or submitted incomplete 3-day dietary food records were excluded from the examination.

Participants' body mass and height were measured twice by means of a standard scale and stadiometer, accurate to within $0.1 \mathrm{~kg}$ and $0.1 \mathrm{~cm}$, respectively. The 
final result was computed on the basis of the arithmetic average of the measurements. During body mass measurements participants were asked to only wear underwear, whereas during height measurements no footwear or socks were allowed.

To assess the energy intake (EI) the method of 3-day dietary food recording was used. The participants completed the recording on 2 training days and 1 day without the training during which there were no official league games. To help determine the portion size, participants used the help of Album of Photographs of Food Products and Dishes (in Polish: Album fotografii produktów i potraw) [35] and website www.ilewazy.pl [17]. These are tools containing a significant number of product and dishes photos presented in various combinations (in cups, on plates, in the palm of a hand, etc.) with the stated product weight. The design of the photos makes it much easier to estimate the mass of the meal consumed, which increases the accuracy of the data obtained in the questionnaire. The energetic value of food intake was estimated by means of Dieta 5.0 software (IŻŻ, Polska).

To measure Total Energy Expenditure (TEE) and Exercise Energy Expenditure (EEE), the Armband SenseWear Pro3 device was used (Body Media Inc., USA). Through galvanometers, heat flow sensors, skin temperature sensor, and a three-axis accelerometer, the device is able to measure the electrical resistance of the skin, the amount of heat released into the environment, movement, intensification of a physical activity and the resulting energy expenditure. According to this construction of the device, it is possible to read the TEE, active energy expenditure (AEE), physical activity level (PAL), the average METs (METs; 1 MET is the equivalent of aspirated oxygen in $3.5 \mathrm{~mL} \mathrm{O} 2 /$ $\mathrm{kg}$ body mass $/ \mathrm{min}$ ), the time expenditure of different intensity activities, and relaxation time expenditure, including resting and sleeping. Research conducted by means of this method is marked by high accuracy measurements $[21,36]$, repeatability (TEE and AEE) [21] and low mean error date [5]. Participants wore armbands on the triceps of their right arm for at least 24 hours. At the time of measurement, the players' training unit was located. After the measurement, from collected records of TEE, an EEE was separated. The Separation of EEE and analysis of the records was completed by means of the SenseWear 8.1. software (Body Media Inc., USA)

The fat free mass content was measured by means of bioelectrical impedance method (BIA), with the use of Akern BIA 101 Anniversary Sport Edition (Akern srl., Italy) device. BIA is a simple, non-invasive and accurate [34], as well as reliable and valid method to body composition assessment [23, 24], showing a low predictive error or standard error [23]. Through the examination, the participants did not suffer from any mental or physical stress. During the measurement, the participants were not during their menstruation. The results were achieved by positioning the participant's limbs in compliance with the producer's instruction. The analysis was carried out in a tetrapolar system. Before placing the electrodes, the contact points were cleaned with alcohol to remove the stratum corneum and dried. The participants were also asked to remove all metal items and jewelry. During the analysis, all the conditions of measurement correctness recommended by the manufacturer were used. The results were analyzed by means of Bodygram 1.31 software.

Energy availability (EA) was calculated conforming to the formula $\mathrm{EA}=(\mathrm{EI}-\mathrm{EEE}) / \mathrm{kg} \mathrm{FFM}$, according to the guidelines contained in the Position of Academy of Nutrition and Dietetics, Dietitians of Canada, and the American College of Sports Medicine [1]. The percentage of training in daily energy needs was calculated according to the formula $\mathrm{TR} \%=(\mathrm{EEE} /$ TEE)*100.

Statistical analysis was conducted by means of the SPSS v. 20 software (IBM Corp., USA). To verify the normality of distribution, the Shapiro-Wilk test was used. To compare obtained results between different groups the ANOVA (in the case of parametric values) and Kruskal-Wallis test (in case of non-parametric values) were applied. The correlation was based on Spearman's test in terms of non-parametric values. Pearson's test was used for correlations in terms of parametric values. The study's defined significance level was set to $\alpha=0.05$.

\section{RESULTS}

The results of anthropometric measurements are presented in Table 1 . The body mass median of players was $58 \mathrm{~kg}(49.1-77.2 \mathrm{~kg})$. The average height in the study group was $166 \pm 5 \mathrm{~cm}$, and the average BMI was $21.4 \pm 2 \mathrm{~kg} / \mathrm{m} 2$. Body composition analysis showed average fat free mass of $42.4 \pm 3.9 \mathrm{~kg}$. We found the significant difference between teams on different league levels in lean body mass content $(p=0.005$, ANOVA). The post-hoc analysis showed that the extra-league team had a higher percentage of fat free mass compared to I league team $(\mathrm{p}=0.027$, Scheffe test) and II league team ( $\mathrm{p}=0.017$, Scheffe test). Other correlations with anthropometric measurements were not found $(\mathrm{p}>0.05)$.

Total energy expenditure, exercise energy expenditure, energy intake, and energy availability are presented in Table 1. TEE in the study group was $2703 \pm 392 \mathrm{kcal} /$ day. Instead, they consumed $1548 \pm 452$ $\mathrm{kcal} /$ day. Energy intake was $1421 \pm 321 \mathrm{kcal} /$ day in the extra-league team, $1577 \pm 497$ in I league team, and $1739 \pm 571 \mathrm{kcal} /$ day in II league team. However, there were no statistical differences between groups. 
Table 1. The results obtained during the measurements in the study

\begin{tabular}{|c|c|c|c|c|c|c|c|c|}
\hline & $\begin{array}{c}\text { Body mass }[\mathbf{k g}] \\
\text { mean } \pm \text { SD } \\
\text { median } \\
\text { min-max } \\
\end{array}$ & $\begin{array}{c}\text { Height }[\mathbf{c m}] \\
\text { mean } \pm \mathrm{SD} \\
\text { median } \\
\text { min-max } \\
\end{array}$ & $\begin{array}{c}\mathbf{B M I}\left[\mathbf{k g} / \mathbf{m}^{2}\right] \\
\text { mean } \pm \mathrm{SD} \\
\text { median } \\
\text { min-max } \\
\end{array}$ & $\begin{array}{c}\mathbf{F F M}[\mathbf{k g}] \\
\text { mean } \pm \mathrm{SD} \\
\text { median } \\
\text { min-max } \\
\end{array}$ & $\begin{array}{c}\text { TEE }[\text { kcal] } \\
\text { mean } \pm \text { SD } \\
\text { median } \\
\text { min-max } \\
\end{array}$ & $\begin{array}{c}\text { EEE }[\text { kcal] } \\
\text { mean } \pm \text { SD } \\
\text { median } \\
\text { min-max } \\
\end{array}$ & $\begin{array}{c}\text { EI [kcal] } \\
\text { mean } \pm \text { SD } \\
\text { median } \\
\text { min-max } \\
\end{array}$ & \begin{tabular}{|c|} 
EA \\
mean \pm SD \\
median \\
min-max \\
\end{tabular} \\
\hline Extra-league & $\begin{array}{c}61.7 \pm 6.7 \\
59.1 \\
54.1-77.2\end{array}$ & $\begin{array}{c}167 \pm 6 \\
167 \\
156-180\end{array}$ & $\begin{array}{c}22 \pm 1.9 \\
22.2 \\
19.6-25.3\end{array}$ & $\begin{array}{c}44.9 \pm 3.6^{*} \\
44.1 \\
40.5-53.9\end{array}$ & $\begin{array}{c}2841 \pm 383 \\
2732 \\
2353-3545\end{array}$ & $\begin{array}{c}503 \pm 63 \\
521 \\
339-578\end{array}$ & $\begin{array}{c}1421 \pm 321 \\
1419 \\
920-1997\end{array}$ & $\begin{array}{c}21 \pm 8 \\
18 \\
9-35\end{array}$ \\
\hline I League & $\begin{array}{c}57.2 \pm 5.9 \\
57.2 \\
49.1-71.3\end{array}$ & $\begin{array}{c}165 \pm 3 \\
166 \\
160-170\end{array}$ & $\begin{array}{c}20.9 \pm 1.8 \\
20.8 \\
17.6-25\end{array}$ & $\begin{array}{c}41.0 \pm 3 \\
40.1 \\
37.6-48.3\end{array}$ & $\begin{array}{c}2743 \pm 327 \\
2827 \\
2256-3253 \\
\end{array}$ & $\begin{array}{c}496 \pm 110 \\
527 \\
203-597\end{array}$ & $\begin{array}{c}1577 \pm 497 \\
1418 \\
923-2606\end{array}$ & $\begin{array}{c}26 \pm 13 \\
23 \\
11-51 \\
\end{array}$ \\
\hline II League & $\begin{array}{c}57.2 \pm 5.9 \\
57.2 \\
49.1-71.3\end{array}$ & $\begin{array}{c}166 \pm 4 \\
165 \\
162-173\end{array}$ & $\begin{array}{c}20.9 \pm 2.4 \\
21.1 \\
18-24.9\end{array}$ & $\begin{array}{c}40.1 \pm 3.6 \\
38.5 \\
37.4-47.1\end{array}$ & $\begin{array}{c}2384 \pm 368 \\
2299 \\
2098-3128 \\
\end{array}$ & $\begin{array}{c}427 \pm 106 \\
449 \\
259-542\end{array}$ & $\begin{array}{c}1739 \pm 571 \\
1951 \\
822-2391\end{array}$ & $\begin{array}{c}33 \pm 11 \\
34 \\
12-44 \\
\end{array}$ \\
\hline Overall & $\begin{array}{c}59.1 \pm 6.5 \dagger \\
58 \\
49.1-77.2\end{array}$ & $\begin{array}{c}166 \pm 5 \\
167 \\
156-180\end{array}$ & $\begin{array}{c}21.4 \pm 2 \\
21.1 \\
17.6-25.3\end{array}$ & $\begin{array}{c}42.4 \pm 3.9 \\
42 \\
37.4-53.9\end{array}$ & $\begin{array}{c}2703 \pm 392 \\
2701 \\
2098-3545\end{array}$ & $\begin{array}{c}483 \pm 94 \dagger \\
515 \\
203-597\end{array}$ & $\begin{array}{c}1548 \pm 452 \\
1419 \\
822-2606\end{array}$ & $\begin{array}{c}25 \pm 11 \\
23 \\
9-51\end{array}$ \\
\hline
\end{tabular}

FFM - Fat Free Mass; TEE - Total Energy Expenditure; EEE - Exercise Energy Expenditure; EI - Energy Intake; EA - Energy Availability [kcal/ $\mathrm{kg}$ fat free mass]

* Significant higher than other groups $(\mathrm{p}<0.05$. ANOVA test)

+ Significant correlation between parameters $(\mathrm{p}<0.05$. Spearman test $)$

Study participants expended $515 \mathrm{kcal}$ (203-597 kcal) on training. The average energy availability in the study group was $25 \pm 11 \mathrm{kcal} / \mathrm{kg}$ fat free mass/day. Eleven soccer players achieved energy availability higher than, or equal to $30 \mathrm{kcal} / \mathrm{kg}$ fat free mass/day, while the additional 3 players approached this number $(>25$ $\mathrm{kcal} / \mathrm{kg}$ fat free mass /day). There were no significant differences between groups ( $\mathrm{p}>0.05$ ANOVA test; $\mathrm{p}>0.05$ Kruskal-Wallis test).
The percentage of energy expenditure related to exercises in total energy expenditure is presented in Figure 1. In the study group, it amounted to $17.93 \pm 3.14 \%$. In the ekstraleague team it amounted to $17.78 \pm 1.7 \%$, in I league team $18.07 \pm 38 \%$, while in II league team $18 \pm 4,4 \%$. There were no significant differences between groups ( $p>0.05$, ANOVA).

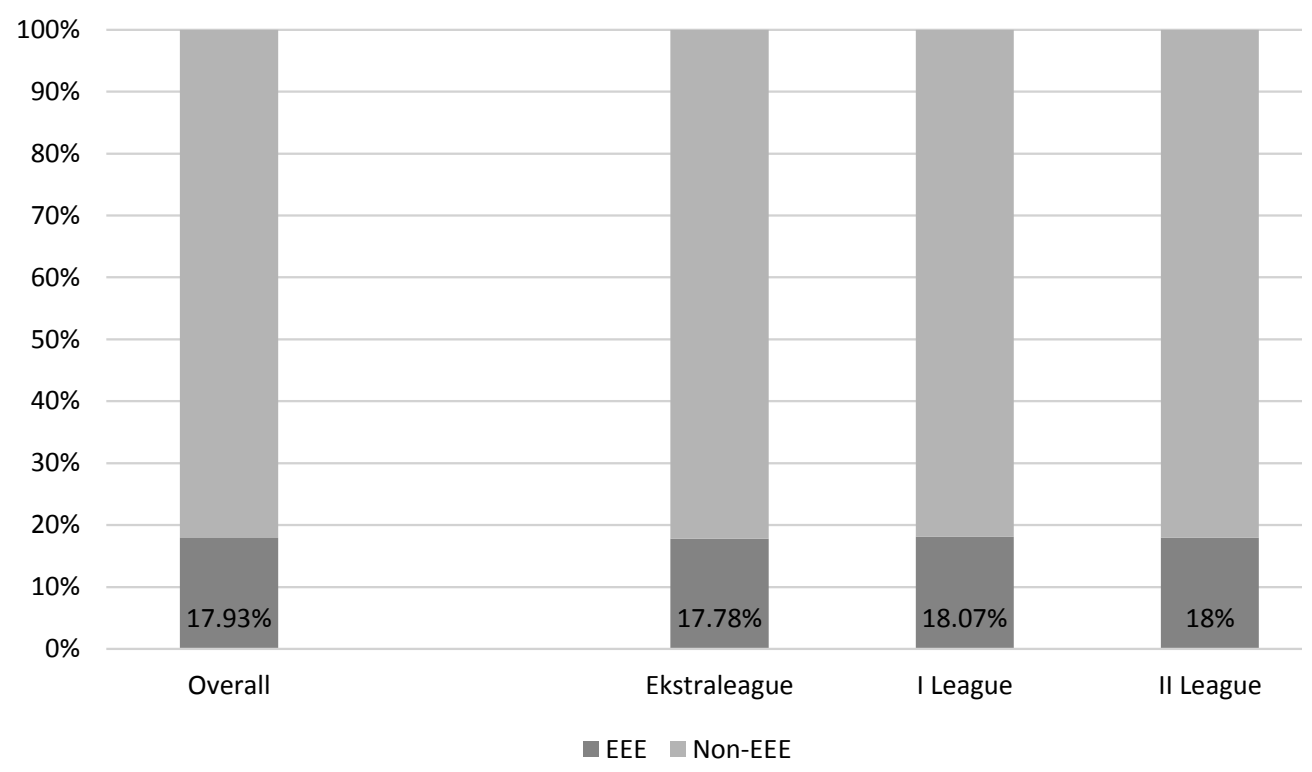

Figure 1. Percentage of Exercise Energy Expenditure (EEE) in daily energy needs

We found a significant correlation between exercise energy expenditure (EEE), and participants ' body mass $(p=0.032$, rho $=0.386$; Spearman test $)$. However, no correlation between EEE and fat free mass was found $(p=0.135$, Spearman test). Also, other correlations between EEE, TEE or EI and other parameters were not found $(p>0.05)$.
Apart from the ones mentioned above, no other statistically significant differences between the groups or correlations between the tested parameters were observed. 


\section{DISCUSSION}

To the best of our knowledge, our study is the first one presenting a low energy availability phenomenon in a group of Polish female soccer players. There is also little research describing this phenomenon among female soccer players in other countries. According to our knowledge, there is also no research comparing the amount of energy availability between teams at different league levels.

Results referring to TEE and EI were presented and published elsewhere [12]. In those studies, an analysis of the fulfillment of daily energy needs (TEE) was carried using the method of 3-day dietary food recording (EI). This research is an analysis of some of the results in relation to the lean body mass of athletes in the context of the phenomenon of low energy availability. Moreover, the subject of the analysis in this study was the share of soccer training in the daily energy needs of female soccer players. It should be pointed, however, that the daily energy needs in the study group were not met, as it was in the case of other authors' studies [13, 25, 28].

Twenty female soccer players (64.1\%) participating in the study did not achieve a limit of $30 \mathrm{kcal} /$ $\mathrm{kg}$ fat free mass/day. With long-term use of such a low-energy diet, serious complications can occur, which can cause both, poor health deterioration and impaired exercise capacity. Slightly better results were obtained in the work conducted by Braun et al., 2018 [6]. They showed that more than half $(53 \%)$ of the elite female soccer players consumed $<30 \mathrm{kcal} /$ $\mathrm{kg}$ fat free mass/day [6]. However, these authors examined the nutritional status of a relatively young group (14.8 \pm 0.7 years old). Such young people very rarely prepare food on their own, which could cause potentially better results than those obtained in our study. In turn, Reed et al. (2013) [31] achieved much better results. In their research with the participation of female soccer players conducted before, in the middle, and also after the end of the soccer season, a low energy availability was observed at $26.3 \%, 33.3 \%$ and $11.8 \%$ women participating in the study, respectively [31]. Our results were obtained in research conducted at the beginning of the soccer season, so the results Reed et al. [31] obtained before the beginning of the soccer season in their study are the closest to compare with results we obtained in our study. Regardless of which moment of the test we choose, all the results are definitely more optimistic than those obtained by us. At each stage of the study, a relatively small percentage of women with low energy availability was detected, compared to our results. It should be noted, however, that 19,15 and 17 women respectively took part in the measurements before, during, and after the soccer season. The difference in results may, therefore, be the result of more women participating in our study. Research on energy availability in female teams was also carried out in the context of other sports. Research conducted with 20 women training Lacrosse on different competitive season moment showed that only in one of the five phases of the study located at different periods during the season, the competitors exceeded the average energy availability of $30 \mathrm{kcal} / \mathrm{kg}$ fat free mass/day. However, in the remaining phases of the study these values were lower [39]. This study did not indicate how large the percentage of the study group did not reach these values though. Surely, better results were presented in their study by Woodruff $\&$ Meloche (2013), wherein studies on 10 volleyball they obtained the results of energy availability at the level $42.5 \mathrm{kcal} / \mathrm{kg}$ fat free mass/day, and only 2 players did not exceed the $30 \mathrm{kcal} / \mathrm{kg}$ fat free mass/day [37]. However, it should be emphasized that this study did not have a large group, hence the results of this study may significantly differ from the others observed in the literature. Research conducted by showed that $30 \%$ of 27 women training football were at risk of low energy availability [10]. However, these studies only calculated the risk of low energy availability using the questionnaire method, they did not include energy expenditure measurement. The results obtained in our study, although in some cases similar to those obtained by other authors, in each case presented a greater number of athletes at risk of the consequences of low energy availability.

The extra-league team had a lower level of energy availability compared to other teams. On the other hand, this relationship was not statistically significant. It could result from a significantly higher lean body mass of the extra-league team, compared to other teams, as well as the lowest EI and the highest EEE. However, this team can feel the negative effects of low energy availability most acutely. In the II league team, in turn, the opposite relationship is observed - higher EI and lower EEE. This team also as the only team presented in this study exceeded the appropriate threshold of available energy and provided $33 \pm 11 \mathrm{kcal} / \mathrm{kg}$ fat free mass/day of energy not spent on training. All teams should, however, strive to increase energy intake with diet, not only to exceed the level of available energy $30 \mathrm{kcal} / \mathrm{kg}$ fat free mass/day but also to reach a level of $45 \mathrm{kcal} / \mathrm{kg}$ fat free mass/day, as a level conducive to optimal health and physical fitness [8].

The percentage share of training in daily energy needs in each team was about $18 \%$, while the average share in the studied group was $17.93 \pm 3.14 \%$. Knowledge of this value can be of great importance for planning optimal around-workout nutrition. Naturally, the percentage of energy distribution for individual meals depends on their quantity. However, it can be a subject to consideration to increase the energetic value 
of meals that are a short distance away from training or constructing separate additional meals at the expense of those further away from physical activity. Meals before, during and after exercise are key to optimizing exercise capacity. The supply of carbohydrates up to 4 hours before physical activity can contribute to increased exercise capacity [7, 15]. Lee et al. (2014) found, that giving women athletes a portion of carbohydrates before starting physical activity contributed to increasing the efficiency of the repeated sprint [19]. Ali et al. (2007), in turn, found that the supply of carbohydrates during exercise made it possible to maintain soccer skills and sprint compared to the placebo group [2]. Also, Russel et al. (2012) in their research showed that the supply of carbohydrates lowered the decrease in performance during the simulated game [33]. Research shows that the supply of $20 \mathrm{~g}$ of proteins or $9 \mathrm{~g}$ of EEA stimulates the process of muscle protein synthesis during and up to 2 hours after exercise [4]. In addition, as demonstrated by Levenhagen et al. (2001), eating a meal immediately after physical activity brought better regenerative effects than if eating this meal 3 hours after the end of activity [20]. In addition, it should be noted that the presence of carbohydrates and proteins in beverages can increase fluid absorption in the small intestine $[16,18]$ which is helpful during the rehydration period. The optimal supply of macronutrients, and thus also the energy value of meals in the period bordering on increased physical activity is, therefore, crucial for maximizing exercise processes and increasing the regeneration and hydration process.

The significant correlation between EEE and the body mass of the players is a relationship that could be expected. Energy expenditure depends on many factors, including body mass. As the exercise intensity during training will be increasing, the energy expenditure will be on the rise too. Given the relationship between body mass and energy needs, one can come to the conclusion that energy expenditure during exercise will increase more in athletes with higher body mass, compared to the participants with lower body mass.

Despite a well-designed study, some of its limitations should be indicated. A small study group may be a less representative sample. Other studies, however, were also conducted on small groups of athletes. In addition, too short a period of measuring energy expenditure can give a misleading picture of energy needs in the studied group. Finally, energy expenditure may vary over the soccer season so measurements should be carried out in different parts of this season. However, the aim of this study was to check what percentage of women training soccer is at risk of low energy availability and its consequences. Because we detected days with low energy availability occurrence, there is a reasonable risk that there may be many more such periods during the season.

\section{CONCLUSIONS}

In conclusion, our results showed low energy availability in a large part of the studied group, which may lead to negative health effects or reduced exercise capacity. A fairly large share of training in daily energy expenditure in the studied group has also been shown which may be an indication for sports nutritionists when planning around-training nutrition. Next studies should be carried out on a larger group, with a longer measurement period spread over different stages of the soccer season. Considering the numerous cases of low energy availability recorded, diagnostics towards the female athlete triad and RED-S in a group of professional female soccer players seems to be advisable.

\section{Acknowledgments}

This research was funded by the Polish Ministry of Science and Higher Education within the funds of the Institute of Human Nutrition Sciences, Warsaw University of Life Sciences (WULS - SGGW) for scientific research.

\section{Conflict of interest}

The authors declare no conflict of interest.

\section{REFERENCES}

1. Academy of Nutrition and Dietetics, American College of Sports Medicine, Dietitians of Canada: Position of the Academy of Nutrition and Dietetics, Dietitians of Canada, and the American College of Sports Medicine: Nutrition and Athletic Performance. J Acad Nutr Diet, 2016; 116(3): 501-528, DOI: 10.1016/j. jand.2015.12.006

2. Ali A., Williams C., Nicholas C.W., Foskett A.: The influence of carbohydrate-electrolyte ingestion on soccer skill performance. Med Sci Sports Exerc, 2007; 39(11): 1969-1976, DOI: 10.1249/mss.0b013e31814fb3e3

3. Beals K.A, Manore M.M.: Disorders of the female athlete triad among collegiate athletes. Int J Sport Nutr Exerc Metab, 2002; 12(3): 281-293 DOI: 10.1123/ ijsnem.12.3.281

4. Beelen M., Burke L.M., Gibala M.J., Van Loon L.J.C.: Nutritional strategies to promote postexercise recovery. Int J Sport Nutr Exerc Metab, 2010; 20: 515-532, DOI: 10.1123/ijsnem.20.6.515

5. Berntsen S., Hageberg R., Aandstad A., Mowinckel P., Anderssen S.A., Carlsen K.H., Andersen L.B.: Validity of physical activity monitors in adults participating in free-living activities. Br J Sports Med, 2010; 44: 657664 DOI: $10.1136 / \mathrm{bjsm} .2008 .048868$

6. Braun H., von Andrian-Werburg J., Schänzer W., Thevis M.: Nutrition Status of Young Elite Female German Football Players., 2018; 30(1): 157-167, DOI: 10.1123/ pes.2017-0072 
7. Burke L.M., Hawley J.A., Wong S.H.S., Jeukendrup A.E.: Carbohydrates for training and competition. J Sports Sci, 2011; 29(SUPPL. 1): S17-S27, DOI: 10.1080/02640414.2011.585473

8. Burke L.M., Loucks A.B., Broad N.: Energy and carbohydrate for training and recovery. J Sports Sci, 2006; 24(7): 675-685 DOI: 10.1080/02640410500482602

9. Clark M., Reed D.B., Crouse S.F., Armstrong R.B.: Preand post-season dietary intake, body composition, and performance indices of NCAA division I female soccer players. Int J Sport Nutr Exerc Metab, 2003; 13(3): 303-319 DOI: 10.1123/ijsnem.13.3.303

10. Condo D., Lohman R., Kelly M., Carr A.: Nutritional intake, sports nutrition knowledge and energy availability in female Australian rules football players. Nutrients, 2019; 11(5): 1-13, DOI: 10.3390/ nu11050971

11. Czaja, J., Lebiedzińska, A., Szefer P.: Sposób żywienia i suplementacji diety reprezentantów polski w biegach średnio- i długodystansowych w latach 2004 - 2005 [Nutritional habits and diet supplementationof Polish middle and long distance representative runners (years 2004-2005)]. Rocz Pzh, 2008; 59: 67-74 (in Polish),

12. Dobrowolski H., Włodarek D.: Dietary intake of Polish female soccer players. Int J Environ Res Public Health, 2019; 16(7): 1134-1145, doi: 10.3390/ijerph16071134

13. Gibson J.C., Stuart-Hill L., Martin S., Gaul C.: Nutrition status of junior elite canadian female soccer athletes. Int J Sport Nutr Exerc Metab, 2011; 21(6): 507-514, DOI: 10.1123/ijsnem.21.6.507

14. Gravina L., Ruiz F., Diaz E., Lekue J.A., Badiola A., Irazusta J., Gil S.M.: Influence of nutrient intake on antioxidant capacity, muscle damage and white blood cell count in female soccer players. J Int Soc Sports Nutr, 2012; 9(1): 32, DOI: 10.1186/1550-2783-9-32

15. Hassapidou M.: Carbohydrate requirements of elite athletes. Br J Sports Med, 2011; 45: e2, http://dx.doi. org/10.1136/bjsm.2010.081570.23

16. Hobson R., James L.: The addition of whey protein to a carbohydrate-electrolyte drink does not influence post-exercise rehydration. J Sports Sci, 2015; 33(1): 77-84, DOI: 10.1080/02640414.2014.925570

17. The ilewazy.pl portal. Availble on www.ilewazy.pl

18. James L.J., Clayton D., Evans G.H.: Effect of milk protein addition to a carbohydrate-electrolyte rehydration solution ingested after exercise in the heat. Br J Nutr, 2011; 105(3): 393-399, DOI: 10.1017/ S0007114510003545

19. Lee C.L., Cheng C.F., Astorino T.A., Lee C.J., Huang H.W., Chang W.D.: Effects of carbohydrate combined with caffeine on repeated sprint cycling and agility performance in female athletes. J Int Soc Sports Nutr, 2014; 11: 17, DOI: 10.1186/1550-2783-11-17

20. Levenhagen D.K., Gresham J.D., Carlson M.G., Maron D.J., Borel M.J., Flakoll P.J.: Postexercise nutrient intake timing in humans is critical to recovery of leg glucose and protein homeostasis. Am J Physiol Endocrinol Metab, 2001; 280: 982-993, DOI: 10.1152/ ajpendo.2001.280.6.E982

21. Liden C.B., Wolowicz M., Stivoric J., Teller A., Vishnubhatla S., Pelletier R., Farringdon J.: Accuracy and Reliability of the SenseWear ${ }^{\mathrm{TM}}$ Armband as an Energy Expenditure Assessment Device. BodyMedia, 2002; 1-15

22. Loucks A.B.: Energy balance and body composition in sports and exercise. J Sports Sci, 2004; 22(1): 1-14, DOI: 10.1080/0264041031000140518

23. Lukaski H.C., Bolonchuk W.W., Hall C.B., Siders W.A.: Validation of tetrapolar bioelectrical impedance method to assess human body composition. J Appl Physiol, 1986; 60: 1327-1332, DOI: 10.1152/jappl.1986.60.4.1327

24. Lukaski H.C., Johnson P.E., Bolonchuk W.W., Lykken G.I.: Assessment of fat-free mass using bioelectrical impedance measurements of the human body. Am J Clin Nutr, 1985; 41: 810-817, DOI: 10.1093/ajcn/41.4.810

25. Martin L., Lambeth A., Scott D.: Nutritional practices of national female soccer players: Analysis and recommendations. J Sport Sci Med, 2006; 5: 130-137

26. Mountjoy M., Sundgot-Borgen J., Burke L., Carter S., Constantini N., Lebrun C, Meyer N., Sherman R., Steffen K., Budgett R., Ljungqvist A., Ackerman K. The IOC relative energy deficiency in sport clinical assessment tool (RED-S CAT). Br J Sports Med, 2015; 49: 1354, http://dx.doi.org/10.1136/bjsports-2015-094873

27. Mountjoy M, Sundgot-Borgen J, Burke L, Carter S, Constantini $N$, Lebrun $C$, Meyer $N$., Sherman R., Steffen K., Budgett R., Ljungqvist A. The IOC consensus statement: Beyond the Female Athlete Triad-Relative Energy Deficiency in Sport (RED-S). Br J Sport Med, 2014; 48: 491-497, http://dx.doi.org/10.1136/ bjsports-2014-093502

28. Mullinix M.C., Jonnalagadda S.S., Rosenbloom C.A., Thompson W.R., Kicklighter J.R.: Dietary intake of female U.S. soccer players. Nutr Res, 2003; 23(5): 585593, https://doi.org/10.1016/S0271-5317(03)00003-4

29. Nattiv A., Loucks A.B., Manore M.M., Sanborn C.F., Sungot-Borgen J., Warren M.P.: American College of Sports Medicine Position Stand: The Female Athlete Triad. Med Sci Sports Exerc, 2007; 39(10): 1867-1882, DOI: 10.1249/mss.0b013e318149f111

30. Nichols J.F., Rauh M.J., Lawson M.J., Ji M., Barkai H.S.: Prevalence of the female athlete triad syndrome among high school athletes. Arch Pediatr Adolesc Med, 2006; 160(2): 137-142, DOI: 10.1001/archpedi.160.2.137

31. Reed J.L., de Souza M.J., Williams N.I.: Changes in energy availability across the season in Division I female soccer players. J Sports Sci, 2013; 31(3): 314 324, DOI: $10.1080 / 02640414.2012 .733019$

32. Rossi K.A.: Nutritional Aspects of the Female Athlete. Clin Sports Med, 2017; 36: 627-653, DOI: 10.1016/j. csm.2017.05.007

33. Russell M., Benton D., Kingsley M.: Influence of carbohydrate supplementation on skill performance during a soccer match simulation. J Sci Med Sport, 2012; 15: 348-354, DOI: 10.1016/j.jsams.2011.12.006

34. Sun S.S., Chumlea W.C., Heymsfield S.B., Lukaski H.C., Schoeller D., Friedl K., Kuczmarski R.J., Flegal K.M., Johnson C.L., Hubbard V.S.: Development of bioelectrical impedance analysis prediction equations for body composition with the use of a multicomponent model for use in epidemiologic surveys. Am J Clin Nutr, 2003; 77: 331-340 DOI: 10.1093/ajcn/77.2.331 
35. Szponar L., Wolnicka K., Rychlik E. (eds): Album fotografii produktów i potraw. Warsaw, IŻŻ, 2000.

36. Teller A.: A platform for wearable physiological computing. Interact Comput, 2004; 16: 917-937, DOI: 10.1016/j.intcom.2004.08.004

37. Woodruff S.J., Meloche R.D.: Energy availability of female varsity volleyball players. Int J Sport Nutr Exerc Metab, 2013; 23(1): 24-30, DOI: 10.1123/ ijsnem.23.1.24
38. Yeager K., Agostini R., NAattiv A., Drinkwater B.: The female athlete triad: disordered eating, amonorrhea, osteoporosis. Med Sci Sports Exerc, 1993; 25(7): 775777, DOI: 10.1249/00005768-199307000-00003

39. Zabriskie H.A., Currier B.S., Harty P.S., Stecker R.A., Jagim A.R., Kerksick C.M.: Energy status and body composition across a collegiatewomen's lacrosse season. Nutrients, 2019; 11(2): 1-11, doi: 10.3390/ nu11020470

Received: 21.01.2020

Accepted: 09.03.2020 